\title{
RANKING OF EPIPHYTIC LICHEN SENSITIVITY TO AIR POLLUTION USING SURVEY DATA: A COMPARISON OF INDICATOR SCALES
}

\author{
H. F. van DOBBEN` and C. J. F. ter BRAAK٪
}

\begin{abstract}
Epiphytic lichens were recorded on wayside trees in the Netherlands. Four statistical methods were used to detect the relationship between presence and abundance of lichen species and measured atmospheric concentrations of $\mathrm{SO}_{2}$, $\mathrm{NO}_{2}$ and $\mathrm{NH}_{3}$. The observed relationships were compared to published indicator scales of lichen sensitivity to atmospheric pollution. For $\mathrm{SO}_{2}$, a good agreement was found between all scales and calculated sensitivities based on presence or absence of species. For $\mathrm{NO}_{2}$ and $\mathrm{NH}_{3}$ the correspondence was less obvious. The sensitivity to $\mathrm{NH}_{3}$ was inversely related to Wirth's acidity indicator scale. Species that react positively to $\mathrm{NH}_{3}$ tend to be sensitive to $\mathrm{SO}_{2}$ and $\mathrm{NO}_{2}$.
\end{abstract}

(C) 1999 The British Lichen Society

\section{Introduction}

Epiphytic lichens are generally considered as good indicators of air quality (Nylander 1866; Herzig et al. 1989; Seaward 1993; Cislaghi \& Nimis 1997). Numerous studies have shown a decline of epiphytic lichens with deteriorating air quality, both in space (de Wit 1976; Hawksworth \& Rose 1970) and in time (Hawksworth et al. 1973; van Dobben 1996). However, these studies were usually hampered by the limited availability of reliable data on air quality. All older studies had to rely on relative measures such as the distance to cities or industrial centres. In later years measurements began to become available, but measuring stations were usually concentrated near pollution sources and absent in 'clean' areas (de Wit 1976). In the Netherlands, however, a country-wide, high-density air quality monitoring network has been operational since 1977 . The data of this network could be combined with observations of epiphytic lichen species at numerous sites throughout the country (van Dobben \& de Bakker 1996), thus allowing an accurate calibration of lichen sensitivities against measured pollutant concentrations.

Previous studies have shown the sensitivity of epiphytic lichens in the Netherlands to $\mathrm{SO}_{2}, \mathrm{NO}_{2}$ and $\mathrm{NH}_{3}$ (de Wit 1976; de Bakker 1989; van Dobben 1993). Sensitivity to $\mathrm{O}_{3}$ may also occur but is hard to detect on the basis of field observations because of the strong negative correlation between concentrations of $\mathrm{O}_{3}$ and $\mathrm{NO}_{2}$ (van Dobben 1993). Scales of lichen sensitivity have been published only with respect to $\mathrm{SO}_{2}$. Of these scales, those

^IBN-DLO, POB 23, NL-6700 AA Wageningen, The Netherlands. E-mail h.f.vandobben@ ibn.dlo.nl (corresponding author) ¥CPRO-DLO (CBW), POB 16, NL-6700 AA Wageningen, The Netherlands. 
by Barkman (1958), Hawksworth \& Rose (1970), de Wit (1976), and Wirth (1991) are the best known. We investigated the relationship between these scales and sensitivities that were derived from measured pollutant concentrations.

There are no published indicator scales for $\mathrm{NO}_{2}$ nor for $\mathrm{NH}_{3}$. The generally accepted ecological classification as 'nitrophytes' and 'acidophytes' (for example Barkman 1958; Wirth 1980; Brand et al. 1988) may be interpreted as a classification of sensitivity to $\mathrm{NH}_{3}$. Wirth's (1991) ' ecological indicator scales' for $\mathrm{pH}$ and nitrogen availability might actually constitute measures for the species' sensitivity to acidifying $\left(\mathrm{SO}_{2}\right.$ and $\left.\mathrm{NO}_{2}\right)$ or nitrogenous $\left(\mathrm{NO}_{2}\right.$ and $\mathrm{NH}_{3}$ ) atmospheric compounds. Wirth's scales are an expansion of Ellenberg's (1991) well-known indicator scales for vascular plants. In these scales, species are ranked according to their response to a number of key environmental variables $(\mathrm{N}$, acidity, light, etc.) on the basis of field data. We investigated the relationship between Wirth's $\mathrm{N}$ and $\mathrm{pH}$ scales, and measures for the species' sensitivities to $\mathrm{SO}_{2}, \mathrm{NO}_{2}$ and $\mathrm{NH}_{3}$ derived from our data.

\section{Materials and Methods}

\section{Data}

The abundance of all lichen species was recorded on groups of ten wayside trees, using a semi-quantitative six-point scale (see van Dobben 1993). The following tree species were used: Quercus robur, Populus $\times$ canadensis, Salix alba, Ulmus $\times$ hollandica, Fraxinus excelsior, and Tilia species. Sampling took place in 1989 on 1216 tree groups that were evenly spread over eight $750-\mathrm{km}^{2}$ regions in the Netherlands. A total of 104 species were recorded. Of these, the 65 species that occurred on ten or more tree groups were used for the present study.

Air pollution data were obtained from the Dutch Air Quality Monitoring Network. $\mathrm{SO}_{2}$ and $\mathrm{NO}_{2}$ were estimated as means of hourly measured concentrations $\left(\mathrm{SO}_{2}\right.$ April-September 1988, $\mathrm{NO}_{2}$ June 1988-May 1989) at monitoring stations (Anonymous 1989, 1990), followed by interpolation (van Egmond et al. 1978) of the concentrations at the epiphyte sampling points. Earlier work (van Dobben 1993) showed that $\mathrm{SO}_{2}$ and $\mathrm{NO}_{2}$ concentrations averaged over these periods yielded the strongest correlation with epiphyte data. Mean $\mathrm{NH}_{3}$ concentrations were estimated on a $5 \times 5 \mathrm{~km}^{2}$ grid basis using the 1988 emission data and the atmospheric transport and deposition model TREND (Asman \& van Jaarsveld 1990). Further details on both epiphyte and air pollution data are given by van Dobben (1993) and van Dobben \& de Bakker (1996).

\section{Statistics}

We used two definitions for sensitivity: (a) the decrease in abundance of a species with increasing pollutant concentration, and (b) the decrease in frequency of a species with increasing pollutant concentration. The latter definition comes closest to the definitions used in other studies, which are usually related to the presence or absence of species and not to their abundance (Seaward 1993). For definition (a), the regression coefficient of a species' abundance on pollutant concentration constitutes a simple measure of sensitivity. For definition (b), logistic regression is the standard technique to relate presence/absence data to pollutant concentrations (Jongman et al. 1995). We performed a multiple regression of abundance [definition (a)] or presence/absence [definition (b)] on environmental variables, including pollutant concentrations. We considered the regression coefficients of the pollutant concentrations as measures of sensitivity. Besides pollutant concentrations we included the following environmental variables in the regression equations: tree species, tree diameter, and distance to the coast. In a previous study (van Dobben \& de Bakker 1996) these variables were shown to have a significant influence on lichen abundance.

Multicollinearity is a common problem in regression studies. In our case the concentrations of $\mathrm{SO}_{2}$ and $\mathrm{NO}_{2}$ were rather strongly correlated $[r=0.49$; see van Dobben (1993) for a complete 
correlation matrix]. As former studies on $\mathrm{SO}_{2}$ sensitivity [for example de Wit (1976) or Hawksworth \& Rose (1970)] did not take account of $\mathrm{NO}_{2}$, we also excluded the $\mathrm{NO}_{2}$ term from the regression equation when determining $\mathrm{SO}_{2}$ sensitivity. The sensitivity to $\mathrm{NO}_{2}$, however, was determined after accounting for the effect of $\mathrm{SO}_{2}$, i.e. with the $\mathrm{SO}_{2}$ term included in the regression equation.

The use of abundance as a measure of sensitivity is complicated by the influence of a species' rarity. Rare species have a low mean abundance, and regressing abundance on pollutant concentrations will therefore yield low regression coefficients for such species. As a result, this method tends to underestimate the sensitivity of rare species. Moreover, it could be argued that abundance can only be used as an estimator for direct environmental factors if a species is present (Tilman \& Olff 1991). In this view, presence or absence itself is determined by other factors, such as dispersal of diaspores. We therefore used two abundance-based measures for sensitivity, one using all data, and the other using only non-zero abundances.

Logistic regression describes the species' response by means of a fixed, S-shaped curve. Other types of response that are biologically feasible, for example the unimodal one, will not be revealed by this technique. In order to overcome this drawback we expanded the logistic model by using 'spline' functions (Hastie \& Tibshirani 1990; Green \& Silverman 1994). This allows more flexibility in the shape of the response curve, comparable to polynomials but avoiding their awkward edge-effects. The flexibility of the spline curve can be expressed by the number of degrees of freedom (Hastie \& Tibshirani 1990). A spline with two degrees of freedom allows the fitting of a unimodal response; a spline with four degrees of freedom allows a bimodal response. For each species and each pollutant we derived an optimal number of degrees of freedom (1, 2 or 4) for the spline as follows. The number of degrees of freedom was increased stepwise and was stopped if the resulting increase in fit was not significant at the $1 \%$ level as judged on the basis of a deviance test (Hastie \& Tibshirani 1990; Jongman et al. 1995).

In summary, four regression techniques were used to determine sensitivity, related to the following equations:

$$
\begin{aligned}
& \text { abundance }=a_{0}+a_{1} \mathrm{SO} 2+a_{2} \mathrm{NO} 2+a_{3} \mathrm{NH} 3+a_{4} \operatorname{diam}+a_{5} \operatorname{coast}+\Sigma_{j}\left(b_{j} \text { treespec }_{j}\right) \\
& \text { non-zero abundance }=\mathrm{a}_{0}+\mathrm{a}_{1} \mathrm{SO} 2+\mathrm{a}_{2} \mathrm{NO} 2+\mathrm{a}_{3} \mathrm{NH} 3+\mathrm{a}_{4} \operatorname{diam}+\mathrm{a}_{5} \operatorname{coast}+\Sigma_{j}\left(\mathrm{~b}_{\mathrm{j}} \text { treespec }_{\mathrm{j}}\right) \\
& \log \left(\frac{p}{(1-p)}\right)=a_{0}+a_{1} \mathrm{SO} 2+a_{2} \mathrm{NO} 2+a_{3} \mathrm{NH} 3+a_{4} \operatorname{diam}+a_{5} \operatorname{coast}+\Sigma_{j}\left(b_{j} \operatorname{treespec}_{j}\right) \\
& \log \left(\frac{p}{(1-p)}\right)=a_{0}+a_{1} \operatorname{SPL}_{q}(\mathrm{SO} 2)+a_{2} \mathrm{NO} 2+a_{3} \mathrm{NH} 3+a_{4} \operatorname{diam}+a_{5} \operatorname{coast}+\Sigma_{j}\left(b_{j} \text { treespec } c_{j}\right)
\end{aligned}
$$

with:

abundance: field-estimated abundance using a logarithmic six-point scale (van Dobben 1993:

$80)$;

non-zero abundance: abundance as above, excluding sites where species is absent;

p: probability of occurrence;

$\mathrm{a}_{0}-\mathrm{a}_{5}$ : regression coefficients;

$b_{j}$ regression coefficient of dummy for tree species $j$;

treespec ${ }_{j}$ : dummy variable for tree species $j$ ( 1 for samples from this tree species, else 0$)$;

$\mathrm{SPL}_{\mathrm{q}}$ : spline function with $\mathrm{q}$ degrees of freedom; $\mathrm{q}=1,2$ or 4 ;

$\mathrm{SO} 2, \mathrm{NO} 2, \mathrm{NH} 3$ : concentrations in air in $\mu \mathrm{mol} . \mathrm{m}^{-3}$ of $\mathrm{SO}_{2}, \mathrm{NO}_{2}, \mathrm{NH}_{3}$, respectively;

diam: tree diameter;

coast: distance to the coast.

Equations similar to (4) were used to fit spline functions for $\mathrm{NO}_{2}$ and $\mathrm{NH}_{3}$. In determining the effect of a given pollutant, the effect of the other pollutants was assumed linear. We did not try spline functions for two or more pollutants simultaneously (as in generalized additive models; Hastie \& Tibshirani 1990) because that would aggravate the problem of collinearity among pollutants. For the determination of the effect of $\mathrm{SO}_{2}, \mathrm{a}_{2}$ was set to 0 .

The spline technique offers no simple measure for sensitivity like the regression coefficient. Therefore, the sensitivity of each species was derived from a dose-response curve (see Fig. 1 for 
examples). This curve was derived from Eq. (4) by inserting mean values for the variables other than the dose variable considered. If the global pattern of the dose-response curve was decreasing, we determined the concentration $\mathrm{C}_{\text {sens }}$ at which the fitted probability of occurrence $(\mathrm{p})$ is half the probability of occurrence at the lowest concentration present in the data $\left(\mathrm{C}_{\min }\right)$; the higher this number, the less sensitive a species (see also Fig. 1a). If there was more than one concentration that meets this requirement, the lowest one was taken.

In practice, not all species appeared to be sensitive in the strict sense, i.e. decreasing with increasing pollutant concentration. For all three pollutants studied, but especially for $\mathrm{NH}_{3}$, there were also species with increasing dose-response curves. In this study such species are termed dependent. If the regression coefficient is used as a measure for sensitivity, dependence will automatically be shown by a positive value. The method used to estimate sensitivity from the spline curves will however not automatically reveal dependence. Therefore we also determined the concentration $\mathrm{C}_{\mathrm{dep}}$ at which the fitted probability of occurrence (p) is half the probability of occurrence at the highest concentration present in the data $\left(\mathrm{C}_{\max }\right)$; the higher this number, the more dependent a species (see also Fig. 1d). If there was more than one concentration that meets this requirement, the highest one was taken.

The final sensitivity $(\mathrm{S})$ was determined as follows:

for sensitive species: $\mathrm{S}=\mathrm{C}_{\max }-\mathrm{C}_{\text {sens }}+2$

for dependent species: $S=C_{\text {min }}-C_{\text {dep }}-2$

Species with a nearly symmetrical unimodal response were excluded from the determination of sensitivity. For some species the value of $\mathrm{C}_{\text {sens }}$ or $\mathrm{C}_{\mathrm{dep}}$ was not within the range of our data (i.e., $\mathrm{C}_{\text {sens }}>\mathrm{C}_{\max }$ or $\mathrm{C}_{\mathrm{dep}}<\mathrm{C}_{\min }$ ). For such species, $\mathrm{S}$ was set to an arbitrary value of 1 (sensitive species) or -1 (dependent species), indicating that these species are the least sensitive and the least dependent ones, respectively. In this way, $S$ is expressed on a scale with the range $(\mathrm{Cmin}-\mathrm{Cmax}-2, \mathrm{Cmax}-\mathrm{Cmin}+2)$, in which positive numbers indicate sensitivity and negative numbers indicate dependence. The values of $\mathrm{C}_{\max }$ are $16.5,41.4$ and $21.1 \mu \mathrm{g} \mathrm{m}^{-3}$, and those of $\mathrm{C}_{\min }$ are $5 \cdot 4,21.5$ and $0.6 \mu \mathrm{g} \mathrm{m}^{-3}$, for $\mathrm{SO}_{2}, \mathrm{NO}_{2}$ and $\mathrm{NH}_{3}$, respectively.

In summary, the above yields four estimators for sensitivity: (1) the linear regression coefficient of abundance on concentration; (2) the linear regression coefficient of non-zero abundance on concentration; (3) the logistic regression coefficient of presence/absence on concentration; and (4) the ' $50 \%$ point' of the fitted response curve using a spline function. These scales were compared with scales from literature by using Spearman's rank correlation test (Snedecor \& Cochran 1989: 194). Therefore all scales were converted to rank numbers. For our results, species were ranked as to decreasing regression coefficient [estimators (1), (2) and (3)], or increasing sensitivity [S in Eqs (5) and (6)], and numbered consecutively (the higher the rank number, the more sensitive; low numbers indicate dependence). For Hawksworth \& Rose's (1970) scale a number was assigned to each species equal to the lowest (i.e., most polluted) zone in which it occurs. For de Wit's (1976) scale, the letters A-H were converted to numbers 1-8. Barkman's (1958) and Wirth's (1991) scale were used directly, being rank numbers themselves; an inverse transformation was applied to Wirth's scale, which is a dependence scale.

Two types of comparison were carried out:

For $\mathrm{SO}_{2}$, the sensitivities determined in this study were compared to four other scales: Barkman (1958), Hawksworth \& Rose (1970), de Wit (1976), Wirth's (1991) toxitolerance;

For $\mathrm{NO}_{2}$ and $\mathrm{NH}_{3}$, the sensitivities determined in this study were compared to Wirth's (1991) $\mathrm{R}$ ( $\mathrm{pH}$ indicator scale), $\mathrm{N}$ (nitrogen availability scale) and To (toxitolerance scale).

All statistical calculations were carried out with the programme package GENSTAT5 release 3 (Payne et al. 1993), which also includes a standard procedure for spline fitting. Only species with more than ten occurrences in our dataset were used. Species that did not show a significant $(P<0.01)$ response to a given pollutant were excluded for that pollutant.

\section{Results}

Table 1 gives the sensitivity values as calculated from the spline-fitted response curves. For all three pollutants most species had a monotonous response (i.e., increasing or decreasing throughout), but unimodal responses (i.e., first increasing, then decreasing) were also found. Figure 1 shows examples of response curves for $\mathrm{SO}_{2}$. Nearly all species were sensitive to $\mathrm{SO}_{2}$. 
TABLE 1. Sensitivity per species to $\mathrm{SO}_{2}, \mathrm{NO}_{2}$ and $\mathrm{NH}_{3}$, derived from the spline-fitted response curves [Eq. (4)]

\begin{tabular}{|c|c|c|c|c|c|c|}
\hline \multirow[b]{3}{*}{ Species } & \multicolumn{6}{|c|}{ Sensitivity } \\
\hline & \multicolumn{2}{|c|}{$\mathrm{SO}_{2}$} & \multicolumn{2}{|c|}{$\mathrm{NO}_{2}$} & \multicolumn{2}{|c|}{$\mathrm{NH}_{3}$} \\
\hline & $\mathrm{df} \neq$ & $\operatorname{sens} \rrbracket$ & $\mathrm{df}$ & sens & $\mathrm{df}$ & sens \\
\hline Bacidia arnoldiana & 1 & $12 \cdot 8$ & $\star$ & $\star$ & $\star$ & $\star$ \\
\hline Buellia griseovirens & 4 & $12 \cdot 6$ & $\star$ & $\star$ & 4 & $-8 \cdot 5$ \\
\hline B. punctata & 1 & $1 \cdot 0$ & 1 & $1 \cdot 0$ & 4 & $-1 \cdot 0$ \\
\hline Caloplaca citrina & 1 & $11 \cdot 5$ & $\star$ & $\star$ & $\star$ & $\star$ \\
\hline Candelaria concolor & 1 & $12 \cdot 2$ & $\star$ & * & 1 & $-20 \cdot 2$ \\
\hline Candelariella reflexa & 1 & $10 \cdot 7$ & $\star$ & $\star$ & 1 & $-14 \cdot 8$ \\
\hline C. vitellina & 4 & $6 \cdot 2$ & $\star$ & $\star$ & 1 & $-11 \cdot 6$ \\
\hline C. xanthostigma & 1 & $11 \cdot 6$ & $\star$ & $\star$ & $\star$ & $\star$ \\
\hline Cladonia species & 1 & $10 \cdot 3$ & $\star$ & $\star$ & 1 & $17 \cdot 5$ \\
\hline Cliostomum griffithii & 1 & $11 \cdot 8$ & $\star$ & $\star$ & 1 & $-19 \cdot 5$ \\
\hline Diploicia canescens & 4 & - & $\star$ & $\star$ & $\star$ & $\star$ \\
\hline Evernia prunastri & 4 & $10 \cdot 4$ & $\star$ & * & 2 & $7 \cdot 3$ \\
\hline Haematomma ochroleucum & 1 & $12 \cdot 9$ & $\star$ & $\star$ & $\star$ & $\star$ \\
\hline Hyperphyscia adglutinata & 1 & $11 \cdot 8$ & $\star$ & $\star$ & $\star$ & $\star$ \\
\hline Hypocenomyce scalaris & 4 & - & 1 & $-19 \cdot 4$ & 1 & $20 \cdot 4$ \\
\hline Hypogymnia physodes & $\star$ & $\star$ & $\star$ & $\star$ & 4 & $15 \cdot 1$ \\
\hline H. tubulosa & 1 & $12 \cdot 8$ & $\star$ & $\star$ & $\star$ & $\star$ \\
\hline Lecanora carpinea & 1 & $11 \cdot 7$ & 2 & $8 \cdot 9$ & 1 & $-17 \cdot 3$ \\
\hline L. chlarotera & 4 & $10 \cdot 1$ & 4 & $6 \cdot 8$ & 1 & $-9 \cdot 9$ \\
\hline L. conizaeoides & 1 & $-6 \cdot 3$ & 1 & $-1 \cdot 0$ & 1 & $15 \cdot 2$ \\
\hline L. dispersa & $\star$ & $\star$ & 1 & $-12 \cdot 1$ & $\star$ & $\star$ \\
\hline L. expallens & 1 & $1 \cdot 0$ & 1 & $\star$ & 1 & $-1 \cdot 0$ \\
\hline L. muralis & 1 & $-10 \cdot 8$ & $\star$ & $\star$ & $\star$ & $\star$ \\
\hline L. pulicaris & 1 & $12 \cdot 9$ & $\star$ & $\star$ & 1 & $-17 \cdot 7$ \\
\hline L. symmicta & 1 & $10 \cdot 4$ & 1 & $10 \cdot 6$ & $\star$ & $\star$ \\
\hline Lecidella elaeochroma & 1 & $10 \cdot 0$ & 4 & - & 1 & $-13 \cdot 3$ \\
\hline Lepraria incana & 1 & $4 \cdot 8$ & $\star$ & $\star$ & 1 & $5 \cdot 4$ \\
\hline Ochrolecia androgyna & 1 & $13 \cdot 9$ & $\star$ & $\star$ & $\star$ & $\star$ \\
\hline Opegrapha atra & 1 & $12 \cdot 4$ & $\star$ & $\star$ & $\star$ & $\star$ \\
\hline Parmelia acetabulum & 2 & $11 \cdot 9$ & 1 & $12 \cdot 3$ & 1 & $-16 \cdot 3$ \\
\hline P. caperata & $\star$ & $\star$ & $\star$ & $\star$ & $\star$ & $\star$ \\
\hline P. exasperatula & 4 & $12 \cdot 9$ & 4 & $21 \cdot 2$ & $\star$ & $\star$ \\
\hline
\end{tabular}

Continued over

For $\mathrm{NO}_{2}$, however, the number of sensitive species only slightly exceeded the number of dependent species, whereas for $\mathrm{NH}_{3}$ about two-thirds of the species were dependent.

When interpreting these results it should be borne in mind that $\mathrm{SO}_{2}$ and $\mathrm{NO}_{2}$ were rather strongly correlated, and that the sensitivity to $\mathrm{SO}_{2}$ was determined without removing the effect of $\mathrm{NO}_{2}$. The ' true' sensitivity to $\mathrm{SO}_{2}$ may therefore be lower than suggested in Table 1 . For $\mathrm{NO}_{2}$, however, the sensitivity displayed in Table 1 was determined after removing the effect of $\mathrm{SO}_{2}$ (this was done by including the term for $\mathrm{NO}_{2}$ in the regression equation). The high number of dependent species for $\mathrm{NO}_{2}$ may therefore be partly an 
TABle 1. Continued.

\begin{tabular}{|c|c|c|c|c|c|c|}
\hline \multirow[b]{3}{*}{ Species } & \multicolumn{6}{|c|}{ Sensitivity } \\
\hline & \multicolumn{2}{|c|}{$\mathrm{SO}_{2}$} & \multicolumn{2}{|c|}{$\mathrm{NO}_{2}$} & \multicolumn{2}{|c|}{$\mathrm{NH}_{3}$} \\
\hline & $\mathrm{df} \ddagger$ & sens $₫$ & $\mathrm{df}$ & sens & $\mathrm{df}$ & sens \\
\hline P. glabratula & 1 & $12 \cdot 8$ & $\star$ & $\star$ & $\star$ & $\star$ \\
\hline P. laciniatula & 1 & $13 \cdot 5$ & $\star$ & $\star$ & $\star$ & $\star$ \\
\hline P. revoluta & 1 & $12 \cdot 1$ & $\star$ & $\star$ & $\star$ & $\star$ \\
\hline P. saxatilis & 1 & $12 \cdot 8$ & $\star$ & $\star$ & 1 & $21 \cdot 5$ \\
\hline P. subaurifera & 4 & $9 \cdot 8$ & $\star$ & $\star$ & 4 & - \\
\hline P. subrudecta & 1 & $6 \cdot 9$ & $\star$ & $\star$ & $\star$ & $\star$ \\
\hline P. sulcata & 4 & $2 \cdot 5$ & 4 & $\star$ & $\star$ & $\star$ \\
\hline P. tiliacea & $\star$ & $\star$ & $\star$ & 夫 & $\star$ & $\star$ \\
\hline Pertusaria albescens & 1 & $11 \cdot 2$ & $\star$ & $\star$ & $\star$ & $\star$ \\
\hline P. amara & 1 & $13 \cdot 4$ & $\star$ & $\star$ & $\star$ & $\star$ \\
\hline P. coccodes & 1 & $12 \cdot 9$ & 1 & $-22 \cdot 0$ & $\star$ & $\star$ \\
\hline P. pertusa & 1 & $12 \cdot 9$ & $\star$ & $\star$ & $\star$ & $\star$ \\
\hline Phaeophyscia orbicularis & $\star$ & $\star$ & 4 & $-10 \cdot 4$ & 1 & $-9 \cdot 3$ \\
\hline Phlyctis argena & 1 & $11 \cdot 8$ & $\star$ & $\star$ & $\star$ & $\star$ \\
\hline Physcia adscendens & 4 & - & $\star$ & $\star$ & 4 & - \\
\hline P. caesia & 2 & $5 \cdot 5$ & 1 & $-7 \cdot 2$ & 1 & $-11 \cdot 2$ \\
\hline P. dubia & 1 & $8 \cdot 5$ & $\star$ & $\star$ & 1 & $-13 \cdot 0$ \\
\hline P. stellaris & $\star$ & $\star$ & $\star$ & $\star$ & $\star$ & $\star$ \\
\hline P. tenella & 1 & $1 \cdot 0$ & $\star$ & $\star$ & 1 & $-1 \cdot 0$ \\
\hline Physconia enteroxantha & 1 & $12 \cdot 2$ & $\star$ & $\star$ & $\star$ & $\star$ \\
\hline P. grisea & 4 & $\star$ & 2 & $-8 \cdot 1$ & $\star$ & $\star$ \\
\hline Placynthiella icmalea & 1 & $10 \cdot 4$ & 1 & $16 \cdot 4$ & $\star$ & $\star$ \\
\hline Protoparmelia hypotremella & 1 & $12 \cdot 1$ & $\star$ & $\star$ & $\star$ & $\star$ \\
\hline Pseudevernia furfuracea & 1 & $12 \cdot 8$ & 1 & $19 \cdot 4$ & $\star$ & $\star$ \\
\hline Pyrrhospora quernea & 1 & $13 \cdot 0$ & $\star$ & $\star$ & $\star$ & $\star$ \\
\hline Ramalina farinacea & 4 & $10 \cdot 4$ & 1 & $4 \cdot 8$ & $\star$ & $\star$ \\
\hline R. fastigiata & 1 & $11 \cdot 8$ & 2 & $7 \cdot 2$ & $\star$ & $\star$ \\
\hline Rinodina exigua & $\star$ & $\star$ & 1 & $-18 \cdot 2$ & $\star$ & $\star$ \\
\hline Usnea species & & & & & & \\
\hline (probably U. subfloridana) & $\star$ & $\star$ & $\star$ & $\star$ & $\star$ & $\star$ \\
\hline Xanthoria calcicola & 4 & - & $\star$ & $\star$ & $\star$ & $\star$ \\
\hline$X$. candelaria & 1 & $7 \cdot 2$ & 1 & $1 \cdot 0$ & 1 & $-1 \cdot 0$ \\
\hline$X$. parietina & 4 & $3 \cdot 3$ & $\star$ & $\star$ & 4 & $-6 \cdot 8$ \\
\hline X. polycarpa & 4 & $8 \cdot 9$ & 4 & $\star$ & 4 & $-1 \cdot 0$ \\
\hline
\end{tabular}

$\Varangle$ Number of degrees of freedom ( ${ }^{\star}$ means no significant $(P<0 \cdot 01)$ response). §Sensitivity determined according to Eqs (5) and (6) ( ${ }^{\star}$ means no significant response, - means unimodal response). Units: $\mu \mathrm{g} \mathrm{m}^{-3}$.

artefact due to the correlation between $\mathrm{NO}_{2}$ and $\mathrm{SO}_{2}$. For $\mathrm{NH}_{3}$ the situation is slightly different. The concentration of $\mathrm{NH}_{3}$ was uncorrelated with the concentrations of $\mathrm{SO}_{2}$ and $\mathrm{NO}_{2}$. Furthermore the effect of $\mathrm{NH}_{3}$ does not come about through its toxicity, but through its effect on bark $\mathrm{pH}$ (van Dobben \& de Bakker 1996). Rather than reducing the total number of species, it causes a shift in the composition of the vegetation, from acidophylic species to acidiphobous species. Apparently the latter group outnumbers the former. 

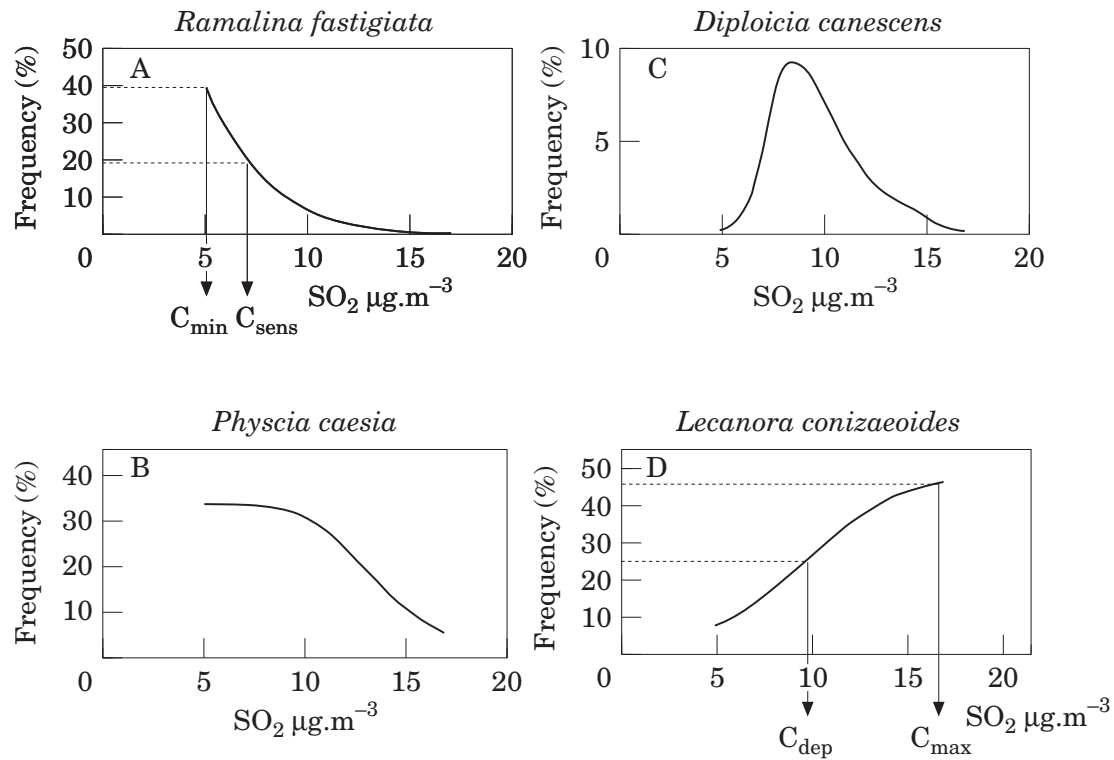

FIG. 1. Examples of spline fitted-response curves for $\mathrm{SO}_{2}$. A, Ramalina fastigiata (sensitive, monotonous response with 1 degree of freedom, $\mathrm{C}_{\text {sens }}=6 \cdot 7 \mu \mathrm{g} \mathrm{m}^{-3}, \mathrm{~S}=11 \cdot 8$ ). $\mathrm{B}$, Physcia caesia (sensitive, monotonous response with 2 degrees of freedom, $\mathrm{C}_{\text {sens }}=13 \cdot 0, \mathrm{~S}=5 \cdot 5$ ). $\mathrm{C}$, Diploicia canescens (unimodal response with 4 degrees of freedom, sensitivity not determined). D, Lecanora conizaeoides (dependent, monotonous response with 1 degree of freedom, $C_{\mathrm{dep}}=9.7 \mu \mathrm{g} \mathrm{m}^{-3}$, $\mathrm{S}=-\cdot 3)$.

The relationship between the sensitivities for $\mathrm{SO}_{2}$ in this study, and the literature values is displayed in Table 2 and Fig. 2. There appeared to be a good agreement between the frequency-related sensitivity measures and the literature values. The spline-fitting method yielded a slightly better correlation with all scales than simple logistic regression. The strongest correlation was found with de Wit's scale. The abundance-related sensitivity measure was only poorly related with the literature values. When zero abundance values were included, a measure was obtained that was even negatively correlated with all sensitivity measures from the literature. Excluding zero abundances yielded a measure that was positively correlated with the literature values. However, only for de Wit's scale was this correlation significant at $P<0 \cdot 05$.

Table 3 gives the relation between the sensitivity measures for $\mathrm{NO}_{2}$ and $\mathrm{NH}_{3}$, and Wirth's (1991) scales for $\mathrm{pH}$, nitrogen and toxitolerance. For $\mathrm{NO}_{2}$ the correspondence appeared to be rather poor. The sensitivity to $\mathrm{NO}_{2}$ determined in this study was uncorrelated with Wirth's toxitolerance and acidity indicator values, and weakly negatively correlated with Wirth's $\mathrm{N}$ indicator values (this relationship was only significant for the frequencyrelated sensitivity). Apparently the species that have a high score on Wirth's $\mathrm{N}$ indicator scale tend to be $\mathrm{NO}_{2}$-dependent in our scale.

For $\mathrm{NH}_{3}$ stronger relationships between the scales were found. The sensitivity to $\mathrm{NH}_{3}$ as determined by all three methods in this study was 
TABLE 2. Relationship between ranked sensitivity per species for $\mathrm{SO}_{2}$ and literature values

\begin{tabular}{|c|c|c|c|c|c|c|c|c|}
\hline \multirow{3}{*}{$\begin{array}{l}\text { Sensitivity }^{\star} \\
\text { abund }\end{array}$} & \multicolumn{8}{|c|}{ Literature values $\ddagger$} \\
\hline & \multicolumn{2}{|c|}{ Barkman } & \multicolumn{2}{|c|}{ H \& R } & \multicolumn{2}{|c|}{ de Wit } & \multicolumn{2}{|c|}{ Wirth } \\
\hline & $-0 \cdot 08^{\mathrm{ns}}$ & $(24)$ & $-0.07^{\mathrm{ns}}$ & (30) & $-0 \cdot 45^{\star \star}$ & (43) & $-0 \cdot 35^{\star \star}$ & $(44)$ \\
\hline nonz-abund & $0 \cdot 39^{\mathrm{ns}}$ & $(10)$ & $0 \cdot 50^{\sim}$ & (13) & $0 \cdot 52^{\star}$ & (17) & $0 \cdot 40^{\mathrm{ns}}$ & (15) \\
\hline freq & $0 \cdot 51^{\star}$ & (21) & $0 \cdot 48^{\star \star}$ & (28) & $0 \cdot 67^{\star \star \star}$ & (40) & $0 \cdot 50^{\star \star \star}$ & (41) \\
\hline spl-sens & $0 \cdot 66^{\star \star}$ & (19) & $0 \cdot 61^{\star \star}$ & (25) & $0 \cdot 84^{\star \star \star}$ & (38) & $0 \cdot 63^{\star \star \star}$ & (39) \\
\hline
\end{tabular}

*Abund=regression coefficient of abundance values on pollutant concentration [Eq. (1)]; nonz-abund = regression coefficient of non-zero abundance values on pollutant concentration [Eq. (2)]; freq=logistic regression coefficient of presence/absence data on pollutant concentration [Eq. (3)]; spl-sens = sensitivity derived by the spline method [Eqs (4), (5) and (6)].

$\ddagger$ Barkman=Barkman (1958: 119) sensitivity scale; H \& R=Hawksworth \& Rose (1970) sensitivity scale; de Wit=de Wit's (1976: Appendix 77) sensitivity scale; Wirth=inverse of Wirth's (1991) toxitolerance scale.

Figures are Spearman's rank correlation coefficients. Significance: $\star \star \star=P \leq 0 \cdot 001$; ${ }^{\star \star}=0.001<P \leq 0.01 ;{ }^{\star}=0.01<P \leq 0.05 ; \sim=0.05<P<0.1 ;{ }^{\text {ns }}=P \geq-\cdot 1$. In brackets: number of species used for the comparison.

Barkman

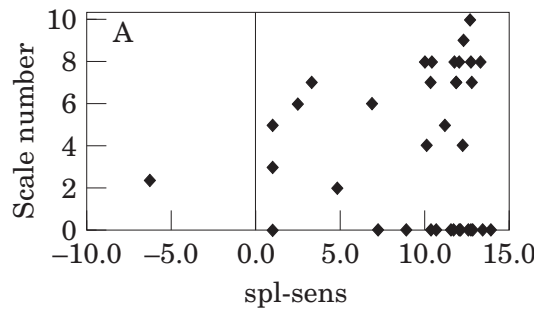

Hawksworth \& Rose

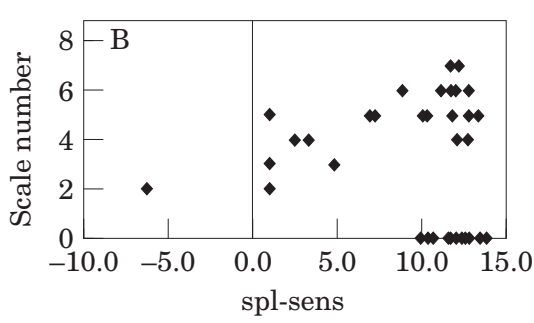

de Wit
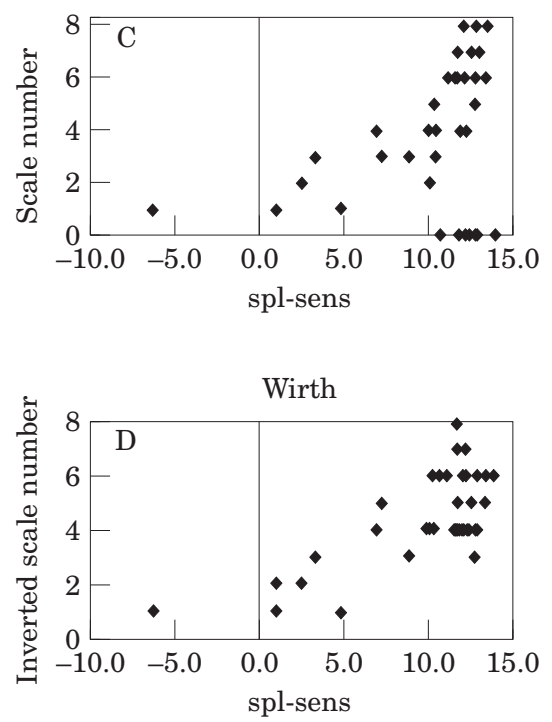

FIG. 2. Scatter diagrams of spline-fitted sensitivity for $\mathrm{SO}_{2}$ against literature values. A, Barkman (1958). B, Hawksworth \& Rose (1970). C, de Wit (1976). D, Wirth (1991), inverted and 10 added. Each diagram contains a selection of the species for which sensitivity estimates exist in the represented scale.

significantly negatively correlated with Wirth's acidity indicator value (R). This means that species with a high $\mathrm{R}$ value in Wirth's scale (i.e., preferring a high bark $\mathrm{pH}$ ) tend to be $\mathrm{NH}_{3}$-dependent on our scale, or vice versa: species 
TABLE 3. Relations between ranked sensitivity per species for $\mathrm{NO}_{2}$ and $\mathrm{NH}_{3}$, and Wirth's (1991) indicator values for acidity, nutrient availability and toxitolerance

\begin{tabular}{|c|c|c|c|c|c|c|}
\hline \multirow[b]{2}{*}{ Sensitivity ${ }^{\star}$} & \multicolumn{6}{|c|}{ Wirth’s indicator values $\ddagger$} \\
\hline & $\mathrm{R}$ & & $\mathrm{N}$ & & To & \\
\hline \multicolumn{6}{|l|}{ A. $\mathrm{NO}_{2}$} & (26) \\
\hline nonz-abund & $0 \cdot 19^{\text {ns }}$ & $(8)$ & $-0 \cdot 09^{\mathrm{ns}}$ & (7) & $0 \cdot 49^{\mathrm{ns}}$ & $(7)$ \\
\hline freq & $-0 \cdot 30^{\mathrm{ns}}$ & $(20)$ & $-0 \cdot 51^{\star}$ & $(19)$ & $0 \cdot 01^{\mathrm{ns}}$ & (18) \\
\hline spl-sens & $-0 \cdot 19^{\mathrm{ns}}$ & (17) & $-0 \cdot 34^{\mathrm{ns}}$ & $(16)$ & $0 \cdot 14^{\mathrm{ns}}$ & (15) \\
\hline \multicolumn{7}{|l|}{ B. $\mathrm{NH}_{3}$} \\
\hline abund & $-0 \cdot 64^{\star \star \star}$ & $(22)$ & $-0 \cdot 63^{\star \star}$ & $(21)$ & $-0 \cdot 01^{\mathrm{ns}}$ & $(18)$ \\
\hline nonz-abund & $-0 \cdot 71^{\mathrm{ns}}$ & (6) & $-0 \cdot 60^{\sim}$ & (5) & $0 \cdot 00^{\mathrm{ns}}$ & $(6)$ \\
\hline freq & $-0 \cdot 46^{\star}$ & $(24)$ & $-0 \cdot 17^{\mathrm{ns}}$ & (23) & $-0 \cdot 33^{\mathrm{ns}}$ & $(21)$ \\
\hline spl-sens & $-0 \cdot 41^{\star}$ & (23) & $-0 \cdot 27^{\mathrm{ns}}$ & $(22)$ & $-0 \cdot 67^{\star \star \star}$ & (20) \\
\hline
\end{tabular}

^Determined as in Table 2 .

$\ddagger \mathrm{R}=$ acidity indicator value; $\mathrm{N}=$ nitrogen indicator value; $\mathrm{To}=$ inverse of toxitolerance indicator value.

Figures are Spearman's rank correlation coefficients. Significance levels as in Table 2. In brackets: number of species used for the comparison.

with a low $\mathrm{R}$ tend to be sensitive to $\mathrm{NH}_{3}$. Furthermore, the abundance-related sensitivity was negatively correlated with Wirth's nitrogen indicator value, and the spline-fitted sensitivity was negatively correlated with Wirth's inverted toxitolerance. Apparently species with a high $\mathrm{N}$ indicator value in Wirth's scale tend to be more abundant in places with high $\mathrm{NH}_{3}$ concentrations, and species that are toxitolerant in Wirth's scale tend to be sensitive to $\mathrm{NH}_{3}$.

\section{Discussion}

There seems to be a fair agreement among the various authors as to the order of species sensitivity to $\mathrm{SO}_{2}$. All scales have a strong correlation with the two measures from this study that are based on presence/absence [' freq' and 'spl-sens' in Table 3, i.e. the measures related to Eqs (3) and (4), respectively]. The correlation with the measures determined in this study on the basis of abundance is much weaker. This is no surprise as all scales are related to the presence or absence of species, although this is not explicitly stated for Wirth's (1991) scale. Apparently it has been possible to determine the relative sensitivities of the species to $\mathrm{SO}_{2}$, even without (Barkman 1958), with very few (de Wit 1976), or with rather crude (Hawksworth \& Rose 1970) pollutant concentration measurements.

For $\mathrm{SO}_{2}$, only Hawksworth \& Rose (1970) relate their scale to absolute concentrations. It has been argued elsewhere (Richardson 1988; van Dobben 1996) that the maximum $\mathrm{SO}_{2}$ concentrations tolerated by lichen species are overestimated using this scale. This view is corroborated by the present data. A species with a sensitivity of 10.0 on our scale (Table 1) has its $50 \%$ reduction point at around $9 \mu \mathrm{g} \mathrm{m}^{-3}$ (namely, $\mathrm{C}_{\max }+2-\mathrm{S}$ [Eq. (5)], with 
$\mathrm{C}_{\max }=16.5 \mu \mathrm{g} \mathrm{m}^{-3}$ and $\mathrm{S}=10 \mu \mathrm{g} \mathrm{m}^{-3}$ ). Such a species will be virtually absent at $20 \mu \mathrm{g} \mathrm{m}^{-3}$ (compare Figs 1a, 1b). The same sensitivity corresponds to approximately scale number 6 in Hawksworth \& Rose's scale (Fig. 2b). However, 6 in the latter scale corresponds to a maximum tolerated $\mathrm{SO}_{2}$ concentration of about $50 \mathrm{\mu g} \mathrm{m}^{-3}$ (Hawksworth \& Rose 1970).

The good correspondence between the different scales for $\mathrm{SO}_{2}$ can be seen as a demonstration of the strength of the effect of this compound on epiphytic lichens [which was also confirmed experimentally, cf. Nash (1988)]. Using highly different methods, and even without proper abiotic measurements, various authors arrived at similar semi-quantitative scales. This is even true for de Wit's (176) scale, which is based on the number of accompanying species, and therefore uses a species' rareness as a measure of its sensitivity (the more common species, the lower the mean number of accompanying species). The implicit assumption is made that $\mathrm{SO}_{2}$ is the only ecological factor that determines whether a species is present or not. Apparently $\mathrm{SO}_{2}$ was a strongly dominant ecological factor at the time (around 1970) and place (the Netherlands) where de Wit's data were collected. However, after this time $\mathrm{SO}_{2}$ concentrations have drastically decreased (Erisman \& Draaijers 1995), and it is questionable whether the same crude method would yield reliable results if applied nowadays.

The negative correlation between the sensitivity values for $\mathrm{SO}_{2}$ from the literature, and the abundance-related sensitivity including zero abundances can be explained from the low mean abundance of rare species and hence, their low regression coefficients in Eq. (1). As rare species are often the sensitive ones, this measure tends to work the opposite way compared to other sensitivity measures. This is especially true for de Wit's scale which itself is in fact an estimate of rarity. This problem can be partly circumvented by excluding zero values, but by doing so the number of observations is greatly reduced, and thereby the number of species with a significant response. This in turn reduces the significance of the correlation between the sensitivities determined in this way and the literature values.

The spline-fitted sensitivity to $\mathrm{SO}_{2}$ has an approximately linear relationship with all four scales from the literature (Fig. 2). This is rather surprising as these scales are not based on direct measurements of $\mathrm{SO}_{2}$. Rather, it seems that all authors have tried to assign approximately equal numbers of species to each class. Apparently species richness decreases more or less linearly with increasing $\mathrm{SO}_{2}$ concentration.

Our data show that the relationship between the presence of lichen species and air pollution can be fairly well described by the classical logistic curve. This is especially true for $\mathrm{SO}_{2}$ where the optimal number of degrees of freedom is one for most species (Table 1). The near-symmetric unimodal response that was found for a few species (Diploicia canescens (Fig. 1c), Physconia grisea, Xanthoria aureola) is most likely an artefact. Probably the geographical distribution of these species is strongly governed by other factors besides $\mathrm{SO}_{2}$. Diploicia canescens, for example, has a strongly coastal distribution, growing inland only along the main rivers. This species is therefore virtually absent from clean inland areas in the Netherlands, and it mainly occurs in areas with intermediate $\mathrm{SO}_{2}$ concentrations. 
TABLE 4. Correlation matrix of spline-fitted sensitivities $\ddagger$

\begin{tabular}{lccc}
\hline & \multicolumn{2}{c}{$\mathrm{SO}_{2}$} & $\mathrm{NO}_{2}$ \\
\hline $\mathrm{NO}_{2}$ & $0.315^{\text {ns }}$ & $(14)$ & \\
$\mathrm{NH}_{3}$ & $-0.383^{\star}$ & $(23)$ & $-0.638^{\sim}(9)$ \\
\hline
\end{tabular}

$\ddagger$ Significance: ${ }^{\star}=P \approx 0 \cdot 05, \sim=P \approx 0 \cdot 08,{ }^{\mathrm{ns}}=P>0 \cdot 1$. In brackets: number of species used for the comparison.

The positive response of Lecanora muralis to $\mathrm{SO}_{2}$ might be an artefact. This species usually occurs on man-made calcareous substrata, but in the southern part of the country (which has relatively high $\mathrm{SO}_{2}$ concentrations) it commonly occurs on dust-impregnated tree bases. The positive response of $L$. conizaeoides to $\mathrm{SO}_{2}$ has been found in many previous studies, including the four indicator scales investigated here, and was also confirmed experimentally (Bates et al. 1996). This species is presently in a process of decline in abundance in western Europe, concurrent with the general decrease in $\mathrm{SO}_{2}$ concentration (van Dobben 1993; Wirth 1993).

For $\mathrm{NH}_{3}$ unimodal responses are more likely to represent a true effect than for $\mathrm{SO}_{2}$, as both sensitive and dependent species commonly occur with the former compound. The species with a unimodal response to $\mathrm{NH}_{3}$ (Parmelia subaurifera and Physcia adscendens) might therefore have a true preference for intermediate $\mathrm{NH}_{3}$ concentrations.

The results of the comparison between the scales for $\mathrm{NO}_{2}$ and $\mathrm{NH}_{3}$ are more difficult to interpret than those for $\mathrm{SO}_{2}$. Wirth's (1991) toxitolerance scale, which is strongly correlated with our (and all other) scales for $\mathrm{SO}_{2}$ sensitivity, is not related with our scales for $\mathrm{NO}_{2}$ sensitivity, and is even negatively related with our spline-fitted $\mathrm{NH}_{3}$ sensitivity. It seems therefore that the suggestion made by the term ' toxitolerance', namely that this scale is related to a general effect of toxic compounds, cannot be maintained. The negative correlation between Wirth's (inverted) toxitolerance and the sensitivity to $\mathrm{NH}_{3}$ determined in this study, suggests that species that are tolerant to $\mathrm{SO}_{2}$ are sensitive to $\mathrm{NH}_{3}$, and vice versa. This is corroborated by a comparison of the spline-fitted sensitivities for the three pollutants (Table 4). The sensitivities to $\mathrm{SO}_{2}$ and $\mathrm{NH}_{3}$ are significantly negatively correlated. This implies that at decreasing $\mathrm{SO}_{2}$ concentration, so-called nitrophytic (i.e., $\mathrm{NH}_{3}$-dependent) species are expected to expand more rapidly than other species. This is in fact what happened in the Netherlands over the period 1980-1990 when the nitrophytic species strongly increased with a regime of decreasing $\mathrm{SO}_{2}$ but constant $\mathrm{NH}_{3}$ concentration (van Dobben \& ter Braak 1998).

Wirth's (1991) acidity indicator scale (R) is significantly negatively related with most of our measures for sensitivity to $\mathrm{NH}_{3}$. Apparently acid-tolerant species (those having a low $\mathrm{R}$ on Wirth's scale) are sensitive to $\mathrm{NH}_{3}$, and vice versa. This is in agreement with the view that the effect of $\mathrm{NH}_{3}$ does not come about through its toxicity but rather through its effect on bark $\mathrm{pH}$ (van Dobben \& de Bakker 1996). In contrast to $\mathrm{SO}_{2}$, including zero values in 
the abundance-related sensitivity to $\mathrm{NH}_{3}$ does not result in a reversal of the sign of the correlation coefficients in Table 3B. A possible explanation is that in general, rare species exhibit the greatest response to $\mathrm{SO}_{2}$, whereas common species have the greatest response to $\mathrm{NH}_{3}$. This is in agreement with the field observation that many rare species have disappeared with increasing $\mathrm{SO}_{2}$ pollution, whereas a small number of common 'nitrophytic' species have increased with increasing $\mathrm{NH}_{3}$ pollution (van Dobben 1986).

Wirth's nutrient indicator scale $(\mathrm{N})$ is weakly negatively correlated with our measures for sensitivity to both $\mathrm{NO}_{2}$ and $\mathrm{NH}_{3}$. This suggests that this scale does not relate directly to nitrogen availability. The difficulty of assigning $\mathrm{N}$ values [in the sense of Ellenberg (1991)] to lichens is discussed by Wirth (1991). It seems that the Wirth's $\mathrm{N}$ scale, at least for epiphytic species, runs more or less parallel with the R scale; i.e., species preferring nutrient-rich bark also prefer bark with a high $\mathrm{pH}$. This is corroborated by the strong correlation $(r=0 \cdot 89)$ between Wirth's $\mathrm{R}$ and $\mathrm{N}$ scales for the species present in our data.

It can be concluded that epiphytic lichens respond to atmospheric pollution. However, claims that these organisms can be used as indicators for a 'general' pollution level, i.e. a summed effect over a variety of pollutants [for example Nylander (1866) or Herzig et al. (1989)], cannot be maintained. Although 60 out of the 65 species considered in this study showed a significant response to any of the pollutants, none of these species were sensitive to all three pollutants (Table 1). A significantly negative response of a majority of the species was found only for $\mathrm{SO}_{2}$ (or rather, the combination of $\mathrm{SO}_{2}$ and $\mathrm{NO}_{2}$, which were strongly correlated). For the other two pollutants both positive and negative responses occurred. Therefore the general level of species richness can only be used as a monitor for $\mathrm{SO}_{2}$. In some situations, however, $\mathrm{SO}_{2}$ itself may be indicative of the general level of atmospheric pollution (Cislaghi \& Nimis 1997). Epiphytic lichens may be useful monitors for pollutants other than $\mathrm{SO}_{2}$, but in that case species have to be separated with respect to their response to the pollutant in question. Methods for monitoring for example $\mathrm{NH}_{3}$ could be devised by using such species weighting (van Herk 1996), but the great sensitivity of most species to $\mathrm{SO}_{2}$ will remain a complicating factor.

\section{REFERENCES}

Anonymous. (1986-1990) Luchtwaliteit-jaarverslagen 1984-1989. Bilthoven: Rijksinstituut voor Volksgezondheid en Milieuhygiëne.

Asman, W. A. H. \& van Jaarsveld, H. A. (1990) A variable-resolution statistical transport model applied for ammonia and ammonium. Bilthoven: National Institute of Public Health and Environmental Hygiene.

Barkman, J. J. (1958) Phytosociology and Ecology of Cryptogamic Epiphytes. Assen: Van Gorcum.

Bates, J. W., McNee, P. J. \& Mcleod, A. R. (1996) Effects of sulphur dioxide and ozone on lichen colonization of conifers in the Liphook forest fumigation project. New Phytologist 132: 653-660.

Brand, A. M., Aptroot, A., de Bakker, A. J. \& van Dobben, H. F. (1988) Standaardlijst van de Nederlandse korstmossen. Wetenschappelijke Mededelingen KNNV 188: 1-68.

Cislaghi, C. \& Nimis, P. L. (1997) Lichens, air pollution and lung cancer. Nature 387: 463-464. de Bakker, A. J. (1989) Effects of ammonia emission on epiphytic lichen vegetation. Acta Botanica Neerlandica 38: 337-342. 
de Wit, A. (1976) Epiphytic lichens and air pollution in the Netherlands. Bibliotheca Lichenologica 5: $1-115$.

Ellenberg, H. Sr. (1991) Zeigerwerte der Gefäszpflanzen (ohne Rubus). Scripta Geobotanica 18: 9-166.

Erisman, J. W. \& Draaijers, G. P. J. (1995) Atmospheric Deposition in Relation to Acidification and Eutrophication. Studies in Environmental Science 63. Amsterdam: Elsevier.

Green, P. J. \& Silverman, B. W. (1994) Nonparametric Regression and Generalized Linear Models: a Roughness Penalty Approach. Monographs on Statistics and Applied Probability 58. London: Chapman \& Hall.

Hastie, T. J. \& Tibshirani, R. J. (1990) Generalized Additive Models. London: Chapman \& Hall.

Hawksworth, D. L. \& Rose, F. (1970) Qualitative scale for estimating sulphur dioxide air pollution in England and Wales using epiphytic lichens. Nature 227: 145-148.

Hawksworth, D. L., Rose, F. \& Coppins, B. J. (1973) Changes in the lichen flora of England and Wales attributable to pollution of the air by sulphur dioxide. In Air Pollution and Lichens (B. W. Ferry, M. S. Baddeley \& D. L. Hawksworth, eds): 330-367. London: Athlone Press.

Herzig, R., Liebendorfer, L., Urech, M., Amman, K., Cuecheva, M. \& Landolt, W. (1989) Passive biomonitoring with lichens as a part of an integrated biological measuring system for monitoring air pollution in Switzerland. International fournal of Environmental Analytical Chemistry 35: 43-57.

Jongman, R. H. G., ter Braak, C. J. F. \& van Tongeren, O. F. R. (1995) Data Analysis in Community and Landscape Ecology. Cambridge: Cambridge University Press.

Nash, T. H. (1988) Correlating fumigation studies with field effects. Bibliotheca Lichenologica 30: 201-216.

Nylander, W. (1866) Les lichens du Jardin du Luxembroug. Bulletin de la Société Botanique de France 13: 364-372.

Payne, R. W., Lane, P. W., Todd, A. D., Digby, P. G. N., Thompson, R., Harding, S. A., Tuncliffe Wilson, G., Leech, P. K., Welham, S. J., Morgan, G. W. \& White, R. P. (1993) GENSTAT5 release 3 Reference Manual. Oxford: Clarendon Press.

Richardson, D. H. S. (1988) Understanding the pollution sensitivity of lichens. Botanical fournal of the Linnean Society 96: 31-43.

Seaward, M. R. D. (1993) Lichens and sulphur dioxide air pollution: field studies. Environmental Reviews 1: 73-91.

Snedecor, G. W. \& Cochran, W. G. (1989) Statistical methods. Ames: Iowa State University Press.

Tilman, D. \& Olff, H. (1991) An experimental study of the effects of $\mathrm{pH}$ and nitrogen on grassland vegetation. Acta Oecologica 12: 427-441.

van Dobben, H. F. (1986) Decline of epiphytic lichens in the Netherlands. Acta Botanica Neerlandica 35: 52-53.

van Dobben, H. F. (1993) Vegetation as a Monitor for Deposition of Nitrogen and Acidity. Utrecht: Ph.D. Thesis.

van Dobben, H. F. (1996) Decline and recovery of epiphytic lichens in an agricultural area in the Netherlands (1900-1988). Nova Hedwigia 62: 477-485.

van Dobben, H. F. \& de Bakker, A. J. (1996) Re-mapping epiphytic lichen biodiversity in the Netherlands: effects of decreasing $\mathrm{SO}_{2}$ and increasing $\mathrm{NH}_{3}$. Acta Botanica Neerlandica 45: 55-71.

van Dobben, H. F. \& ter Braak, C. J. F. (1998) Effects of atmospheric $\mathrm{NH}_{3}$ on epiphytic lichens in the Netherlands: the pitfalls of biological monitoring. Atmospheric Environment 32: 551-557.

van Egmond, N. D., Tissing, O., Onderdelinden, D. \& Bartels, C. (1978) Quantitative evaluation of mesoscale air pollution transport. Atmospheric Environment 12: 2279-2287.

van Herk, C. M. (1996) Monitoring van ammoniak en zwaveldioxide met korstmossen in de provincie Utrecht. Soest: LON.

Wirth, V. (1980) Flechtenflora. Stuttgart: Ulmer.

Wirth, V. (1991) Zeigerwerte von Flechten. Scripta Geobotanica 18: 215-237.

Wirth, V. (1993) Trendwende bei der Ausbreitung der anthropogen geförterten Flechte Lecanora conizaeoides? Phytocoenolgia 23: 625-636. 